\title{
British Champions of Peirce
}

\section{Christopher Hookway}

\section{(2) OpenEdition}

\section{Journals}

Electronic version

URL: http://journals.openedition.org/ejpap/482

DOI: 10.4000/ejpap.482

ISSN: 2036-4091

\section{Publisher}

Associazione Pragma

\section{Electronic reference}

Christopher Hookway, "British Champions of Peirce », European Journal of Pragmatism and American Philosophy [Online], VI-1 | 2014, Online since 08 July 2014, connection on 17 March 2020. URL : http:// journals.openedition.org/ejpap/482 ; DOI : https://doi.org/10.4000/ejpap.482

This text was automatically generated on 17 March 2020.

\section{(c) $(1) \&$}

Author retains copyright and grants the European Journal of Pragmatism and American Philosophy right of first publication with the work simultaneously licensed under a Creative Commons AttributionNonCommercial-NoDerivatives 4.0 International License. 


\title{
British Champions of Peirce
}

\author{
Christopher Hookway
}

When the history of American philosophy in the nineteenth century can be written in great detail than hitherto, the important place of Charles S. Peirce as a pathfinder in every one of the many fields that his work touched will have to receive fuller recognition than has as yet been accorded to it.

1 This quotation is from "Charles Peirce's Pragmatism," a paper by John Henry Muirhead that was published in The Philosophical Review in 1930s. It is evidence that the value of Peirce's work was recognized in the 1930s. But Peirce's work had been recognized even earlier than this. One of the earliest indications of this was reflected in the fact that Mind had published a positive review of Peirce's Illustrations of the Logic of Science. His works were also taken seriously in the following years.

2 Two thinkers had been especially effective in spreading the word of Peirce's importance. One of these is Frank Ramsey, who worked extensively on induction and probability. He appealed to Peirce's account of induction on several occasions. Ramsey also drew attention to Peirce's work on signs. In his review of Wittgenstein's Tractatus Logico-Philosophicus, Ramsey suggested that the book would have benefited from the use of Peirce's distinction between types and tokens.

3 The second was Victoria, Lady Welby, a member of the Bloomsbury Group with great interests in semiotics, the theory of signs. She wrote several books defending "Significs." Her correspondence with Peirce is a major source of information about Peirce's writings on the theory of signs, and she worked hard to encourage the spread of Peirce's work in the United Kingdom. One product of this is an extended discussion of Peirce's work on signs in The Meaning of Meaning, an influential book by Ogden (the translator of the Tractatus) and I. A. Richards. Their book would have ensured that Peirce's work was well known, even if it didn't receive extended discussion and admiration in philosophical circles. Moreover, Peirce's work on induction continued to be known, not least from the writings of Braithwaite's Scientific Explanation: A study of Theory, Probability and Law in Science.

4 Peirce's work was also known though the work of Muirhead's The Platonic Tradition in Anglo-Saxon Philosophy: Studies in the History of Idealism in England and America. Muirhead was, for many years, Professor of Philosophy in the University of Birmingham. Peirce 
and Royce were the only American philosophers to deserve chapters, although Peirce had only one chapter while Royce had five.

Muirhead's chapter on Peirce began with a section on the "Anti-Hegelian Reaction." The chapter described Peirce's logic and pragmatism as well as taking account of tychism, and devoting a section to the "Reconstruction" towards idealism. He was described as "a Germinal" thinker.

6 After the 1930s, Peirce scholarship continued to prosper, but little of it was based in the United Kingdom. In the 1930s, W. B. Gallie wrote an elegant and valuable book on Peirce and Pragmatism, published by Penguin Books; I can testify to its role in introducing many young philosophers to Peirce's work, but, under the influence of Wittgenstein and Oxford philosophy, few British philosophers were sufficiently stirred by pragmatism or pragmaticism for Peirce to become a major topic for research. We also see a growing interest in Ramsey's work, particularly in Cambridge, to the degree that some people talk of the "Cambridge Pragmatists" in UK as well as those from Harvard.

7 During the 1950s and 1960s, British philosophy was dominated by Oxford philosophy and Wittgenstein, so that Peirce's work was not much discussed. Things began to change in the 1970s. In the UK, in Warwick, Susan Haack wrote some influential papers on Peirce and began her work using pragmatist ideas for research, and she has continued to do so having moved to the USA. Christopher Hookway published three books on Peirce from 1985 to 2014. After a general study of Peirce's philosophy, Peirce (1985), he wrote Truth Rationality of Pragmatism: Themes from Peirce (2002) and The Pragmatic Maxim Essays on Peirce and Pragmatism (2013). These included discussions on the pragmatic maxim, both the formulation of Peirce's pragmatic maxim and his reasons for accepting it. There were also papers on truth and on Peirce's views about rational self-control. Haack has also supervised Ph.D. students on Peirce, as has Hookway in Sheffield.

\section{AUTHOR}

\section{CHRISTOPHER HOOKWAY}

University of Sheffield, UK

c.j.hookway[at]sheffield.ac.uk 